\title{
Analysis of Relationship of Obesity and Diabetes Mellitus in Local Population of Pakistan
}

\author{
Muhammad Usman Saddique*1, Noman Ashrif ${ }^{2}$ and Asim iqbal ${ }^{3}$ \\ ${ }^{1}$ Working as MO at BHU 92 JB Gojra, Pakistan \\ ${ }^{2}$ In charge health officer BHU Kassesay, Pakisthan \\ ${ }_{3}^{3}$ innah hospital Lahore, Pakisthan
}

Submission: June 08, 2018; Published: June 15, 2018

*Corresponding author: Muhammad Usman Saddique, Working at BHU 92 JB Gojra, Pakistan, Email: Sheikhusmansiddique365@gmail.com

Abstract

Introduction: Worldwide, Indo-Asian people are among the populations at highest risk for cardiovascular disease. Evidence also suggests that associations between body mass index (BMI), percentage of body fat and chronic disease may differ between Indo-Asian and European populations.

Objectives of the study: Our study objective is to find the analysis of relationship of obesity and diabetes mellitus in local population of Pakistan.

Methodology of the study: The study was conducted at Jinnah Hospital Lahore during 2017 to 2018 . There was 100 patients which was visit the hospital during this time period. We assess the nutritional and economic health of patients by asking some survey questions.

Analysis and results: The demographic and social values shows that obesity has a direct link with diabetes. It shows that people consume more protein and fat as compared to carbohydrates. Due to this reason they may suffer from other diseases parallel to diabetes.

Conclusion: It is concluded that there is a direct relationship of obesity and diabetes. If the diabetic person does not follow the instructions related to diet they must lead to some other issues which may lead to death.

Keywords: Diabetes; Obesity; Diseaes

\section{Introduction}

Diabetes is a major cause of mortality globally, and it has been estimated that 400 million people worldwide will suffer from it by 2030. Despite the fact that hereditary qualities seems to assume an essential part in the advancement of diabetes, examine recommends that dietary decisions driven by natural and financial components are of critical significance. Amazing eating regimens assume an essential part in diabetes avoidance [1]. Suitable dietary adherence can enhance insulin affectability and glycemic control, and consequently add to way of life change and general personal satisfaction. Worldwide, Indo-Asian people are among the populations at highest risk for cardiovascular disease [2]. Evidence also suggests that associations between body mass index (BMI), percentage of body fat and chronic disease may differ between Indo-Asian and European populations [3]. One proposed explanation for these observations is the effect of poverty and resultant malnutrition during intrauterine and early childhood years, coupled with relative over nutrition in later years [4].
The 2013 American Diabetes Association (ADA) standards of care prescribe an individualized way to deal with basic leadership as to protein admission and dietary macronutrient composition [3]. Factors to be considered incorporate the metabolic status of the patient (e.g., lipid profile, renal capacity) and additionally food inclinations [5]. With regards to diabetes, the monetary moderateness (e.g., food security), availability, and agreeableness (e.g., food culture) have been talked about as potential boundaries to meeting and adherence to prescribed dietary rules [6]. The eating routine wellbeing behavior of diabetes patients and techniques to conquer potential obstructions to adherence to prescribed dietary rules are key general wellbeing and diabetes wellbeing concern. In this manner, there is have to measure the connection between eat less quality, corpulence, and diabetes [7].

\section{Objectives of the Study}

Our study objective is to find the analysis of relationship of obesity and diabetes mellitus in local population of Pakistan. 


\section{Global Journal of Otolaryngology}

\section{Methodology of the Study}

The study was conducted at Jinnah Hospital Lahore during 2017 to 2018. There was 100 patients which was visit the hospital during this time period. We assess the nutritional and economic health of patients by asking some survey questions. From the large pool of data we select health status, diet quality, lifestyle, food culture, food security, and demographic information of the selected patients. The economic and health status describe the level of awareness regarding disease. The collected data were analyzed using SPSS software (version 17). The results are presented as a mean with $95 \%$ confidence interval limits or standard deviations. The significant value for $\mathrm{P}$ $<.05$ was accepted as statistically significant.

\section{Analysis and Results}

The data was collected from 100 male and females patients who visit the health care center. The analysis of the data shows that diabetes is more common in females as compared to males. We also collect the basic characteristics of patients and compared these values with normal values. So we can find that diseases person have more blood pressure value as compared to normal. People who suffer from diabetes also suffer from high blood pressure problem (Tables 1-3).

Table 1: Basic characteristics of patients.

\begin{tabular}{|c|c|}
\hline Diseases age & $35 \pm 5$ \\
\hline Poor class & $49 \%$ \\
\hline Middle class & $40 \%$ \\
\hline Upper class & $10.7 \%$ \\
\hline educated & $11.7 \%$ \\
\hline Illiterate & $55 \%$ \\
\hline Active life style & $25 \%$ \\
\hline Normal life style & $67 \%$ \\
\hline
\end{tabular}

Table 2: Demographic characteristics and history of patients.

\begin{tabular}{|c|c|c|}
\hline Variables & Co-efficient & SE \\
\hline $\begin{array}{c}\text { Blood pressure } \\
\text { Healthy eating index } \\
\text { (HEI) }\end{array}$ & 0.048 & 0.35 \\
\hline Smoker & -0.059 & 0.05 \\
\hline Food security & 0.060 & 0.80 \\
\hline Drinker & -0.343 & 0.12 \\
\hline Belong to city area & 0.057 & 0.08 \\
\hline Belong to rural area & 0.59 & 0.01 \\
\hline BMI & 0.5460 .24 & 0.70 \\
\hline
\end{tabular}

Note: explains the demographical conditions of the patients. This table explains the co-efficient and standard error values. The level of confidence interval is 90 and 95 in this table for the significant value.

Indicate significance at the 99, 95, and 90\% level.

Table 03 explains the relationship between dietary intake, BMI and diet quality among diabetic patients. It shows that people consume more protein and fat as compared to carbohydrates. Due to this reason they may suffer from other diseases parallel to diabetes.
Table 3: Relationship between supplement intake, BMI, and diet quality among diabetes patients.

\begin{tabular}{|c|c|c|}
\hline Variables & Co-efficient & SE \\
\hline \multicolumn{2}{|c|}{ Dietary supplements } \\
\hline Carbohydrate & 0.019 & 0.03 \\
\hline Protein & 0.061 & 0.08 \\
\hline Amino acid & 0.106 & 0.19 \\
\hline Fat & 0.434 & 0.02 \\
\hline Lipids & 0.057 & 0.01 \\
\hline BMI of diseased person & 0.29 & 0.07 \\
\hline
\end{tabular}

\section{Discussion}

A worldwide epidemic exists with respect to diabetes mellitus because of increased rates of obesity. There is a significant correlation between obesity and insulin resistance and obesity causes the increase in the severity of the disease [8]. The adipose tissues in the visceral region function as an endocrine organ that produces certain proteins with role in glucose homeostasis. The expression level of some of these proteins is increased in diabetes and can serve as specific marker of the disease [9]. The study was performed to check the effect of various physical and biochemical parameters of obesity on the development and progression of diabetes mellitus. In our study the serum samples of diabetics were collected and were further categorized into two groups i.e. diabetic obese and diabetic non obese, on the basis of BMI, waist circumference and waist to hip ratio. The fasting blood sugar level, the total protein content, along with the complete lipid profile was performed [10].

As an outcome, these patients devoured diets with a lower glycemic record and glycemic stack esteems as contrasted and patients in the unhealthy eating pattern. Presently, diets with a low glycemic list have been related with enhanced glycemic control [11-15]. Another supplement likely identified with the best watched glycemic control in our investigation is dietary fiber. In like manner, in our patients in the healthy eating pattern, a higher aggregate, dissolvable, and insoluble fiber utilization was watched. It has just been exhibited that a high fiber intake was related with better glycemic control in patients with diabetes. In any case, up to now, the advantageous effects of fiber intake, particularly solvent fibers, couldn't be detached from the effects of glycemic list and glycemic stack in light of the fact that most foods that have a low glycemic file additionally have a high fiber content [16].

\section{Conclusion}

It is concluded that there is a direct relationship of obesity and diabetes. If the diabetic person does not follow the instructions related to diet they must lead to some other issues which may lead to death. 


\section{References}

1. Wheeler ML, Dunbar SA, Jaacks LM, Karmally W, Mayer-Davis EJ, et al. (2012) Macronutrients, food groups, and eating patterns in the management of diabetes: a systematic review of the literature, 2010. Diabetes Care 35(2): 434-445.

2. A Jala O, English P, Pinkney J (2013) Systematic review and metaanalysis of different dietary approaches to the management of type 2 diabetes. Am J Clin Nutr 97(3): 505-516.

3. Newby PK, Tucker KL (2004) Empirically derived eating patterns using factor or cluster analysis: a review. Nutr Rev 62(5): 177-203.

4. Ocké MC (2013) Evaluation of methodologies for assessing the overall diet: dietary quality scores and dietary pattern analysis. Proc Nutr Soc 72(2): 191-199.

5. Viana LV, Gross JL, Camargo JL, Zelmanovitz T, da Costa Rocha EP, et al. (2012) Prediction of cardiovascular events, diabetic nephropathy, and mortality by albumin concentration in a spot urine sample in patients with type 2 diabetes. J Diabetes Complications 26(5): 407-412.

6. Hallal PC, Matsudo SM, Matsudo VKR, Araújo TL, Andrade DR, et al. (2005) Physical activity in adults from two Brazilian areas: similarities and differences. Cad Saude Publica 21(2): 573-580.

7. Sarmento RA, Riboldi BP, da Costa Rodrigues T, de Azevedo MJ, de Almeida JC (2013) Development of a quantitative food frequency questionnaire for Brazilian patients with type 2 diabetes. BMC Public Health 9(13): 740.

8. Wang Q, Xia W, Zhao Z, Zhang H (2015) Effects comparison between low glycemic index diets and high glycemic index diets on HbA1c and fructosamine for patients with diabetes: a systematic review and meta-analysis. Prim Care Diabetes 9(5): 362-369.

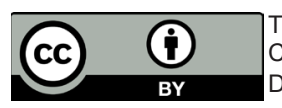

This work is licensed under Creative Commons Attribution 4.0 License DOI: $10.19080 / G J O .2018 .16 .555933$
9. Oza-Frank R, Cheng YJ, Narayan KM, Gregg EW (2009) Trends in nutrient intake among adults with diabetes in the United States: 19882004. Journal of the American Dietetic Association 109(7): 1173-1178.

10. Meloni C, Morosetti M, Suraci C, Pennafina MG, Tozzo C, et al. (2002) Severe dietary protein restriction in overt diabetic nephropathy: benefits or risks? J Ren Nutr 12(2): 96-101.

11. Kopple JD (2001) National kidney foundation K/DOQI clinical practice guidelines for nutrition in chronic renal failure. American journal of kidney diseases 37(1 Suppl 2): S66-S70.

12. Azadbakht L, Esmaillzadeh A (2009) Soy-protein consumption and kidney-related biomarkers among type 2 diabetics: a crossover, randomized clinical trial. Journal of renal nutrition: the official journal of the Council on Renal Nutrition of the National Kidney Foundation 19(6): 479-486.

13. Silva FM, Kramer CK, de Almeida JC, Steemburgo T, Gross JL, et al. (2013) Fiber intake and glycemic control in patients with type 2 diabetes mellitus: a systematic review with meta-analysis of randomized controlled trials. Nutr Rev 71(12): 790-801.

14. Garshick M, Mochari-Greenberger H, Mosca L (2014) Reduction in dietary Trans fat intake is associated with decreased LDL particle number in a primary prevention population. Nutr Metab Cardiovasc Dis 24(1): 100-106.

15. Azadbakht L, Fard NR, Karimi M, Baghaei MH, Surkan PJ, et al. (2011) Effects of the Dietary Approaches to Stop Hypertension (DASH) eating plan on cardiovascular risks among type 2 diabetic patients: a randomized crossover clinical trial. Diabetes Care 34(1): 55-57.

16. Paula TP, Viana LV, Neto AT, Leitão CB, Gross JL, et al. (2015) Effects of the DASH diet and walking on blood pressure in patients with type 2 diabetes and uncontrolled hypertension: a randomized controlled trial. J Clin Hypertens (Greenwich) 17(11): 895-901.

\section{Your next submission with Juniper Publishers will reach you the below assets}

- Quality Editorial service

- Swift Peer Review

- Reprints availability

- E-prints Service

- Manuscript Podcast for convenient understanding

- Global attainment for your research

- Manuscript accessibility in different formats

( Pdf, E-pub, Full Text, Audio)

- Unceasing customer service

Track the below URL for one-step submission https://juniperpublishers.com/online-submission.php 